Neeka, J

Repositioning PTDF as a Source of Cutting-Edge Research in the Oil and Gas Industry: A Collaborative and Innovative Strategies for Knowledge Management.

\author{
n.jacob@ptdf.gov.ng \\ Strategic Planning, Research and Development Department, Petroleum Technology Development Fund, PTDF, \\ 2 Memorial Drive, CBD,Abuja, Nigeria. \\ This article is covered and protected by copyright law and all rights reserved exclusively by the \\ Centre for Petroleum, Pollution Control and Corrosion Studies (CEFPACS) Consulting Limited. \\ Please note that the opinion expressed in this article remain that of the author(s). \\ Electronic copies available to authorised users.
}

The link to this publication is https://ajoeer.org.ng/otn/ajoeer/qtr-1/2021/10.pdf 


\title{
Repositioning PTDF as a Source of Cutting-Edge Research in the Oil and Gas Industry: A Collaborative and Innovative Strategies for Knowledge Management.
}

\author{
Neeka, $\mathrm{J}^{1}$ Mannir, $\mathrm{A}^{1}$, Agboola, $\mathrm{O}^{1}$ and Haruna, $\mathrm{M}^{2}$ \\ n.jacob@ptdf.gov.ng
}

1. Strategic Planning, Research and Development Department.

2. Administration and Human Resource Management Department.

Petroleum Technology Development Fund, PTDF, 2 Memorial Drive, CBD, Abuja, Nigeria.

\begin{abstract}
.
The mandate of an organization is fundamental to achieving its objectives in society and the Petroleum Technology Development Fund is not an exception. Research Development and Innovation is one of the Key mandates of the PTDF and repositioning it for the desired purposes in the industry is in high demand and of necessity. In this paper, strategic approaches developed to reposition the research focus of the Fund is examined. Challenges and opportunities are highlighted for possible frontier expansion and restructuring at optimal levels. Oil and Gas industry is highly technical and competitive, requiring the use of the best technologies in solving problems and research development and innovations is the bedrock in achieving and sustaining such goals. The primary purpose of the PTDF as a technology development agency of government must be redirected with state-of-the-act policy to drive research as a cutting-edge tool for national economic development. Secondly, this paper identified key knowledge enablers and inhibitors to the use of research information for industrial development. Accordingly, this paper is useful for research design, policy formulation and structural reform in research development and innovative cycle for the energy industry and other sectors of the economy. Finally, this paper will serve as a source document for the expansion project on research restructuring in Oil and Gas in Nigeria.
\end{abstract}

Keywords: Research Development and Innovation, Strategic Knowledge Enablers and Inhibitors, Frontier Basins, Collaboration and Linkages.

\section{0: INTRODUCTION.}

Historically, the Petroleum technology Development Fund (PTDF) was established by Act 25 of 1973 as amended in Cap 15 of 2000 to replace the former Gulf Oil Company Training Fund Act 1964, with the mandate to train Nigerian for the Oil and Gas industry. From its transformation as a desk office in Department of Petroleum Resources (DPR) to a full fledge government agency in 2000, the aspiration of government remains to grow, increase and sustain local participation of Nigerians Content in the oil and gas industry. The Petroleum Technology Development Fund (PTDF) core mandate is to develop capacity, capability and competent Nigerians for improved oil and gas exploration, exploitation and production in the upstream, midstream and downstream sub-sectors.

It also includes infrastructural and institutional base development as well as the promotion of research, invention and acquisition of relevant innovative technologies, to keep the PTDF at the mainstream of oil and gas technology development in Nigeria and the West African Sub-region (Agboola, 2018). Research and Development involves networking and sharing of ideas through collaboration, innovation and strategic knowledge management for efficient service to the industry. Sequel to the quest to build on the 3 - Helix structure of the industry, academia and government, the PTDF cutting - edge research and development programmes have several streams structurally modelled to enhance local 
capacity, retain such capacity in the industry (Local Content), improve technology development and acquisition, reduce cost and improve productivity etc.

Furthermore, it is no longer a new fact that nations like America, United Kingdom, Germany, Canada, South Africa, Russia, China, Japan, India have over the years, huge budget and continued investment in research and technology development to gain and retain their competitive advantage in the comity of nations. Research and Development has increased and advanced their economies, create large scale enterprises, small and medium scale companies, improve transportation, sustained clean environments and improve living standards through poverty minimization. Research and Development is essential to stay ahead, and it is instrumental to creating new products or adding innovative values to existing old products. It also implies the investment in ideas and products which are capable of being transformed into a new products, processes and services.

A retrospective assessment of the over seven decades of Oil and Gas operation in Nigeria, established the fact that International Oil Companies and National Oil Companies with other growing service providers have evolved greatly on the back of Research and Development. Such frontline companies are ExxonMobil, Total, Shell Petroleum Development Company (SPDC), Chevron, Eni NAOC, Seplat Petroleum, Addax, NNPC, NPDC, Snepco Schlumberger, Halliburton, Atlas, Waltersmith, Annoil Services etc.

There are fundamental problems that PTDF researches were designed to solve in the oil and gas industry including environmental bioremediation, wax deposition problems, waste to wealth through effective engineering design and production, source rocks evaluation, reservoir stabilization and wellbore chemical modelling and refinery zeolite catalyst development etc. These researches were developed to actualize the core and critical mandate of the Fund, which is to develop indigenous manpower and domicile Oil and Gas technology through optimal engagement of local researchers in solving industry problems.

\section{1: Research Policy and Strategic Direction.}

Research development and deployment of technologies are operational in strategic policies that are prioritize in concrete terms in compliance with the Fund's mandate. To actualize the purpose, a balance score-card approach is adopted to strategically delineate research activities with a view to optimize processes in financial management, internal business control, stakeholder engagement and capacity building through learning and growth process.

Policy alignment with national and global industry realities in research and development are anchored on: (i) domestication of the research to stem escalating costs and maximizing the benefits through indigenous engagement of local researchers. (ii) creating linkages with Nigerian and International Oil and Gas industries to ensure that capacities of Nigerians, innovations and inventions developed from research activities are seamlessly realised through increased participation in the oil and gas value chain. (iii) Utilization of centres of excellence in strategic locations across the country to drive cutting-edge researches with high potentials to produce intellectual properties, commercialize research products through spin-off and start-up companies. (iv) Ensure efficient and sustainable funding plan through timely releases of funds for effective research activities. (v) Reposition the Fund's research structural management systems through the engagement of industry players, carry out needs assessment, develop skills and technologies to solve specific problems. 
These new strategic direction in research, are predicated on the need to create and execute profitable business model and source partnership for the expansion of research collaboration and linkages as new frontiers for the Fund.
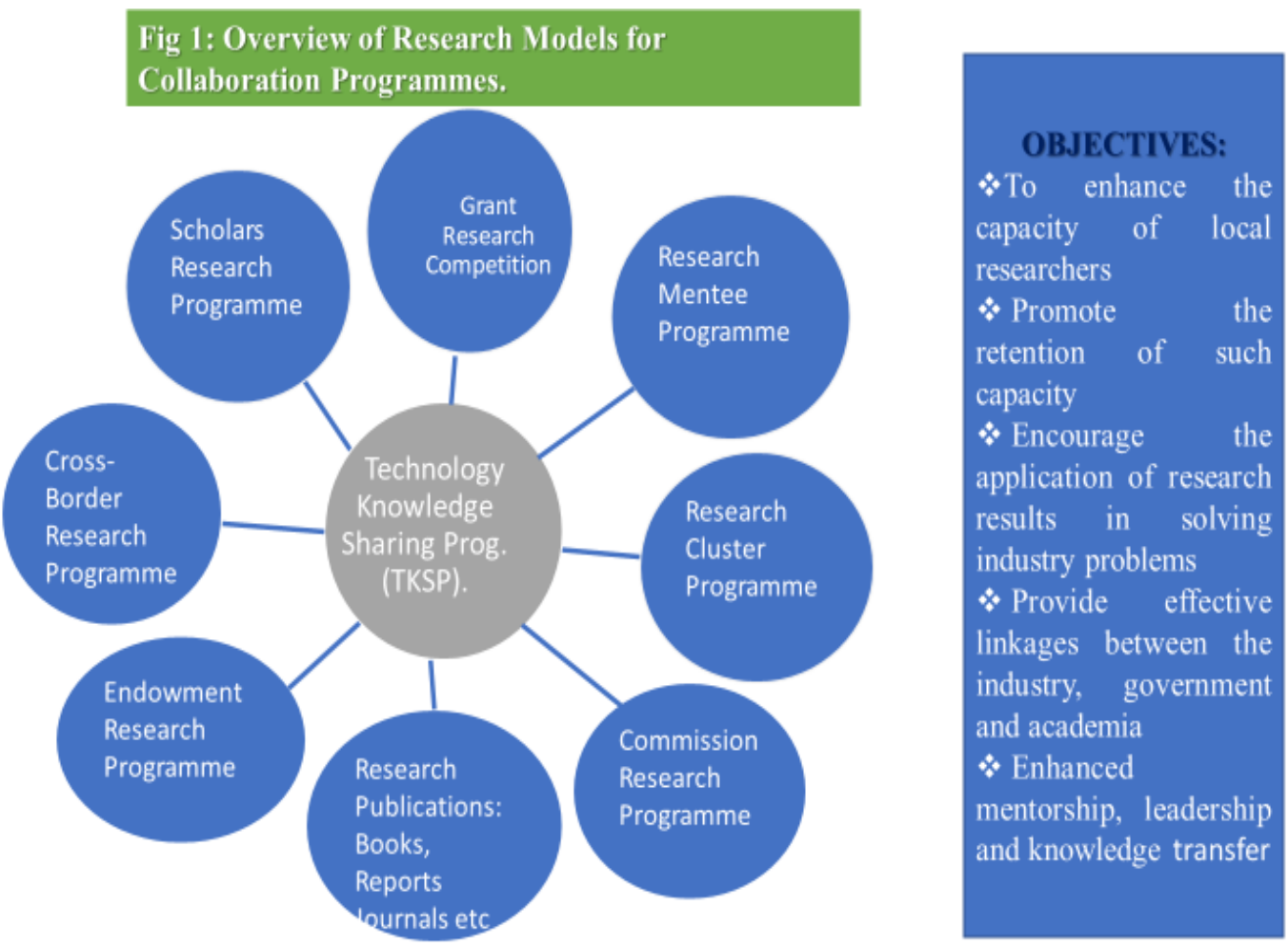

Fig 1: Overview of Research Models for Collaboration.

\section{0: REVIEW OF RELATED LITERATURES.}

The concept of repositioning research implies that there exists, research structures that fail to meet the expectation of the end users. Interestingly, research is the capacity to effectively utilize time and resources to find, discover, review, gather, analyse, discuss, conclude and recommend (using novel and innovative techniques) solutions to identified or unexpected problems, optimize the process to ensure minimal harm to the environment, Making the listed research methodologies efficient is very essential for generating expected products.

2.1: Research Classification: Research can be classified according to planned target goals, expected outcomes and research effects on the environment (Neeka, 2020). Some of the classifications used in the industry includes: (i) Cross-border research: It is a multidisciplinary modular teaching and supervisory model between two or more institutions on a collaborative basis; suitable and operational in the industry for rapid techno- innovative capacity building and optimization. (ii) Scholar's research: it's a studentbased research with emphasis on degree certificate award; may be funded by government agencies, international and national oil companies, individual or a foundation.

Study period is between three to five years and this highly competitive in its selection process. (iii) Research Cluster is a segmentation of research areas using experts' skills and experiences in solving 
multiple problems from a single research design; very complex to manage but useful in cost saving for time-based operations in the field. (iv) Commissioned research is a one off, short term investigative research specifically tailored to solve an identified problem using the well-established expertise of an individual or group within limited time; produces a quick win solution that will enhance policy formulation for more detailed research.

Duration is within three months to one year. (v) Mentee research is a highly professional handson practical research training that emphasizes acquisition of skills and technology, ultimately making the mentee an expert or consultant in the area of training. It has prompt delivery with certificate of competence or attestation from the mentor. (vi) Grant research is one of the oldest, has an annual call for proposal and mostly twenty-four-month duration per cycle. Grant research is broad and covers all areas of research activities in the industry, with an initial step that requires the researcher to submit concept note or proposal before actual budget line item; may not run for two or three years per cycle, with emphasis on solving industry problems, generating inventions and innovations for optimization. (vii) Endowment research is a university-based research with an initial lump sum seed money as endowment fund.

It's usually very prestigious with a qualified professor as the occupant; the aim is to build capacity and initiate applied research and training for spin-off while solving varied industry problems.; may advance into centre of excellence over time because of seemingly adequate funding. (viii) collaboration and linkage research are an inter-agency model with the involvement of memorandum of understanding to guide the scope and mode of counterpart responsibility. May be drawn on long term collaboration with defined milestones and key performance indicators etc. The endower may be a corporate entity, individual or a foundation for research activities and notable contribution to knowledge, (Neeka et al, 2018).

\section{0: MATERIALS AND METHODS}

Several methods have been designed to give research programmes of the Fund an industry buy-in and acceptable application. These include the development of standards for conducting research in the Fund, a template which identifies criteria that must be met in industry-based research. Selection and composition of committees of experts that scrutinize research proposals and review research outcomes on regular basis. The management standards for setting up minimum laboratory analysis and engineering equipment in compliance with global best practices. Others include the use of experienced supervisory mechanism of professionals drawn from the industry, academia and the government for periodic evaluation of the research cycles.

The thematic research design process, which seek to solve identified problems at the beginning of the research process and ultimately, strong and timely funding support that guarantee completion of the various research projects. The emphasis on proper documentation of research reports and registration of intellectual property rights and patents are fundamental springboards for research expansion strategies of the Fund. The use and deployment of virtual technology in research programme management as a consequence of the coronavirus pandemic (COVID-19) has helped in cost-saving and safety improvement for the effective and efficient growth of research-based programmes of the Fund. 


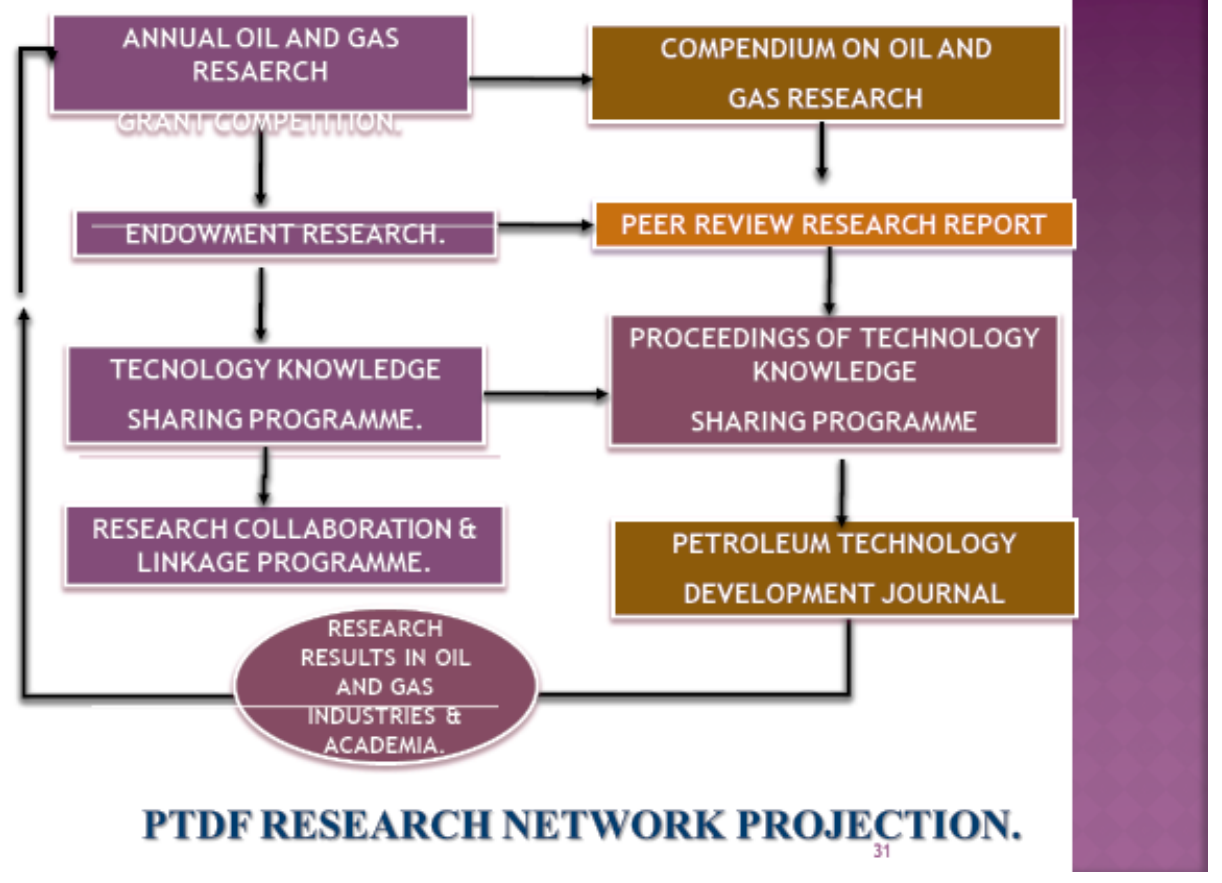

\section{1: The Research Expansion Strategies.}

Research and Development strategies of the Fund have grown tremendously in recent years; focus have been on the deployment of research breakthroughs to solving identified industry problems. The PTDF research models are based on a tripod of endowment research in eight universities, research grant awards that run for two years per cycle and cluster research that is specifically a callup need for at least five years on an identified industry problem.

The Petroleum Technology Development Fund has registered and obtained several patents on its funded researches including; Database for wellbore stability management in the Niger Delta; Control of fine migrations in reservoirs using nanoparticles, production of fuel briquettes and bio-gas from cow dung mixtures for domestic and agro-industrial applications, Development and production of Zeolite Y catalyst from locally source kankara Clay deposits in Nigeria, Development of Viable technology for the Production of Biodiesel from Oils of Non-edible Seeds etc. All those researches are at present, being deployed in the industry, contributing immensely in reducing huge capital flights associated with the importation of such technologies and services by the oil and gas majors in the country.

Tremendous impact has also been made in scholars research including those studying at the master's and PhD levels, with several inventions and innovations recorded in recent times. For instance, in 2017, a scholar from Herriot Watts University, United Kingdom, invented the Symmetric Reflective Compound Parabolic Concentrator (SRCPC) capable of generating $7.66 \mathrm{~W}$ at $1200 \mathrm{w} / \mathrm{m} 2$ electricity during indoor conditions. Another scholar developed a simplified matrix in Mathematics for secondary schools, while yet another scholar developed the fundamental of mechatronic engineering for security applications and environmental monitoring in Nigeria. The out-break of the global pandemic, coronavirus has further broadened the available technologies in-country from the research scholars funded by PTDF. The invention of and manufacture of several designs of ventilators, Unmounted vehicles (UMV) for surveillance and distribution of health facilities, automated tunnel sanitizers, face-shields and hand sanitizers etc. are some derivable benefits of the PTDF programmes to the country, (Haruna, 2018). 


\section{2: Cost Reduction Management Approach.}

A fundamental necessity in evaluating high profile research breakthrough impact, is the ability to cut down on cost while maintaining high content at specified time, (Bamiro, 2019). The PTDF adopted the cost saving approach through the reduction in lag-time while increasing the productive period through adequate and structured supervisions of each of the research projects. Timeline drawn for specific tasks and timely release of funds for the implementation of the scheduled work plans were useful strategies in the cost reduction drive. Besides, timely monitoring and evaluation at every phase of the research activities, using specialists in each field and on each team contributed immensely in adding value to the completed work while reducing cost of implementation. Pre-engagement exercise of the Steering Committee Members (SCM), of the research programme, helped to reduce the number of days of meeting for the SCM. Peer review exercise thus reduced to once in a cycle and close-out sessions also reduced from three to two days with the same quality of delivery and results.

Application of the developed technologies in Enterprise Content Management approach (ECM) for the virtual supervision, meeting and review processes of strategic nodes in PTDF funded researches has helped to fast-track implementation of research programmes, (COVID-19 Report, 2020). Thus, documentation and achieving of recorded and printed proceedings have been enhanced for timely referral and review purposes. Customized software has been developed for specific research projects that enabled access to must-do lists and standards, reporting pattern, scoring and grading systems for selected researches as well as ranking for final approval. These are novel techniques that have strategically placed the PTDF research administration strategies above board in Nigeria.

\section{3: Research Collaboration and Linkages.}

Flowing from the various success stories recorded in the field of applied research so far, the Fund has engaged seriously with stakeholders and other agencies of the government and private sector investors to collaborate and open linkages in developing cutting edge researches for the petroleum industry. The collaboration with the Nigerian National Petroleum Corporation (NNPC), was designed to ease the accessibility to research laboratory equipment from upstream mid and downstream operations. Analytical equipment is source of capital flight for researchers. It also adds to lag time, especially in coding and obtaining analytical results from laboratories overseas. Another collaboration with the Dangote Refinery is aimed at utilizing the Zeolite Y, ZSM - 5 in the refinery when completed.

The PTDF- NOSDRA collaboration, essentially on the establishment of Oil spill Detection Platform in-country was driven by the University of Surrey, United Kingdom's interest in managing oil spill sites to preserve the ecosystem. The platform will also serve as research center for real time tracking, and prevention of oil spills by sabotage practices. Another collaboration between the PTDF - NCDMB model is aimed at implementing the local content policy, and effectively utilizing the research results and product of researches to solve identified oil-spills and other related problems. This is a great contribution of the PTDF to raising the bar in locally funded researches for global applications.

\section{4: Knowledge Management Strategies.}

The concept of knowledge management as an enabler and solution to improved industrialization and economic development has long been established, (Darma and Jacob, 2012). However, slow acceptance of new and emerging knowledge in the petroleum sector constitute threats to sustainable development. Knowledge management is an implicit variable in human capital development, economic growth and 
technology transfer in all facets of life. Knowledge is vital to research and, its dissemination encourage and facilitate collaboration, linkages and techno-economic fusion of organizations or research partners. The PTDF knowledge enablers and management strategies conceptually designed in the context of its vision, conversation, activities, function and management are embedded in the following (i) Technology Knowledge Sharing Programme (ii) Petroleum Technology Development Journal (iii) Compendium on Oil and Gas Research (iv) Peer Review Research Report (v) Exhibition and Linkages etc. These knowledge enablers provide enough details on each programme to justify the act of knowledge creation for an expanded research aimed at growing both human capacity and technology for the industry in Nigeria.

\section{0: RESULTS AND DISCUSSIONS}

The achievements of the research initiative of the PTDF from 2002 to 2019 in the three main streams of funded researches are highlighted in the table hereunder. These three main streams include the grant, endowment and scholar's researches respectively. Table 1 represents the registered intellectual properties and patents as a function of the viability of the Fund's research programmes in-country. The approved patents are fundamental to growing the next phase of developing start-up companies for the commercialization or production of the research outcomes or deployment of the product of research for industrial and commercial use. The solution inherent in each patent remain a abstract until the product is commercialized for everyday use.

The endowment researches started in 2002, and from conceptualization and research patent, more funding and capacity building had taken place. Thus, key value additions and technology development in the areas of Oil and Gas have been enhanced through the endowment research programme of the Fund. There are strategic endowments in eight Federal Universities and, the prospects of expanding the frontiers to include smart-tech development in communication and robotics, and artificial intelligence are being considered.

Table 1: Intellectual Property Rights and Patents of funded Researches.

\begin{tabular}{|l|l|l|l|l|}
\hline S/No & Research Type & Research Topic & Patent Reg. Number & $\begin{array}{l}\text { Authors } \\
\text { Profile }\end{array}$ \\
\hline 1. & $\begin{array}{l}\text { Endowment } \\
\text { Research. }\end{array}$ & $\begin{array}{l}\text { Petroleum Products } \\
\text { Adulterate Meter }\end{array}$ & NG/PT/NC/2019/3976 & $\begin{array}{l}\text { Olotu, } \\
\text { Oalbisi } \\
\text { Oluseyi and } \\
\text { Isehunwa, } \\
\text { Sunday } \\
\text { Oloruntoba }\end{array}$ \\
& & & & \\
\hline
\end{tabular}




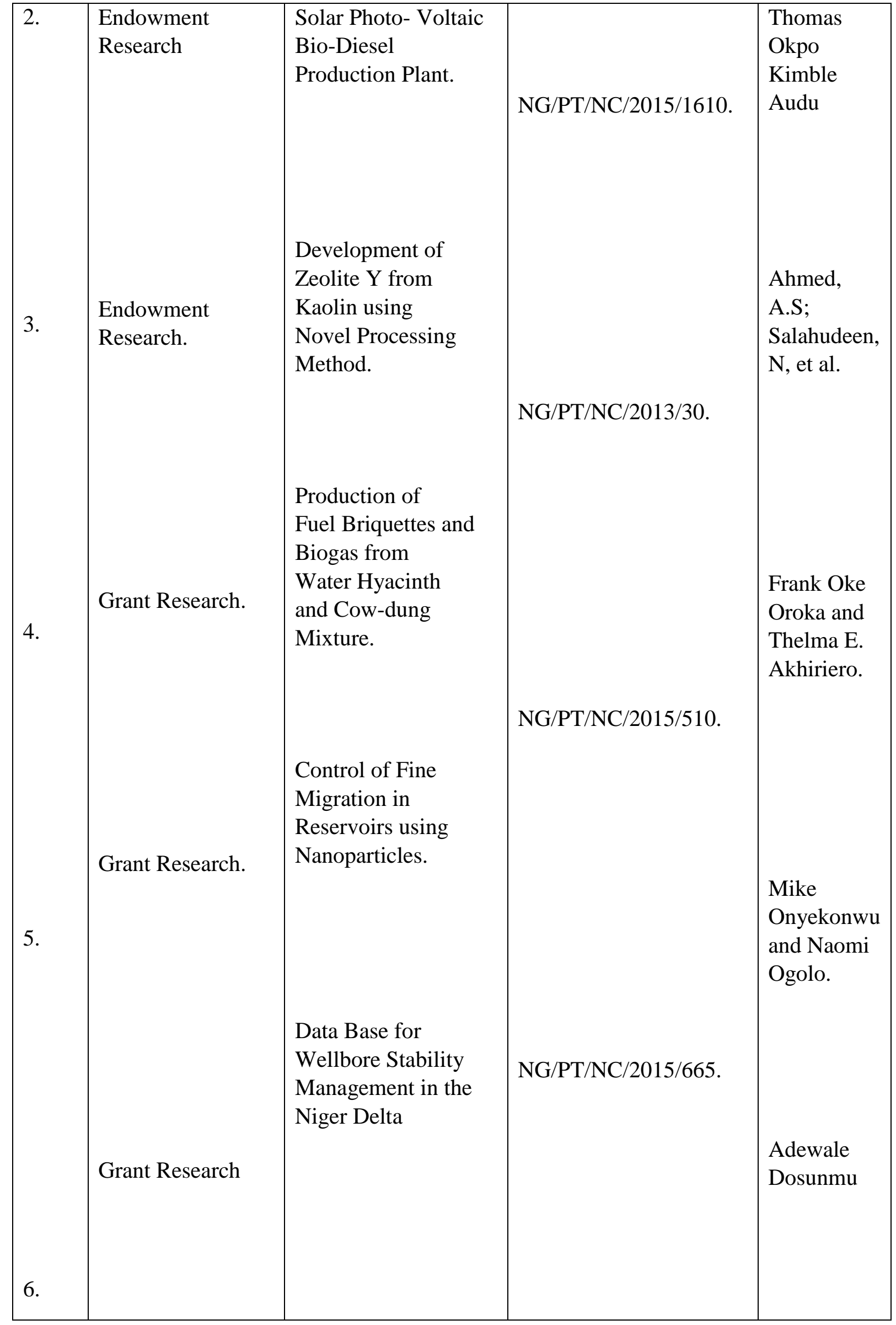




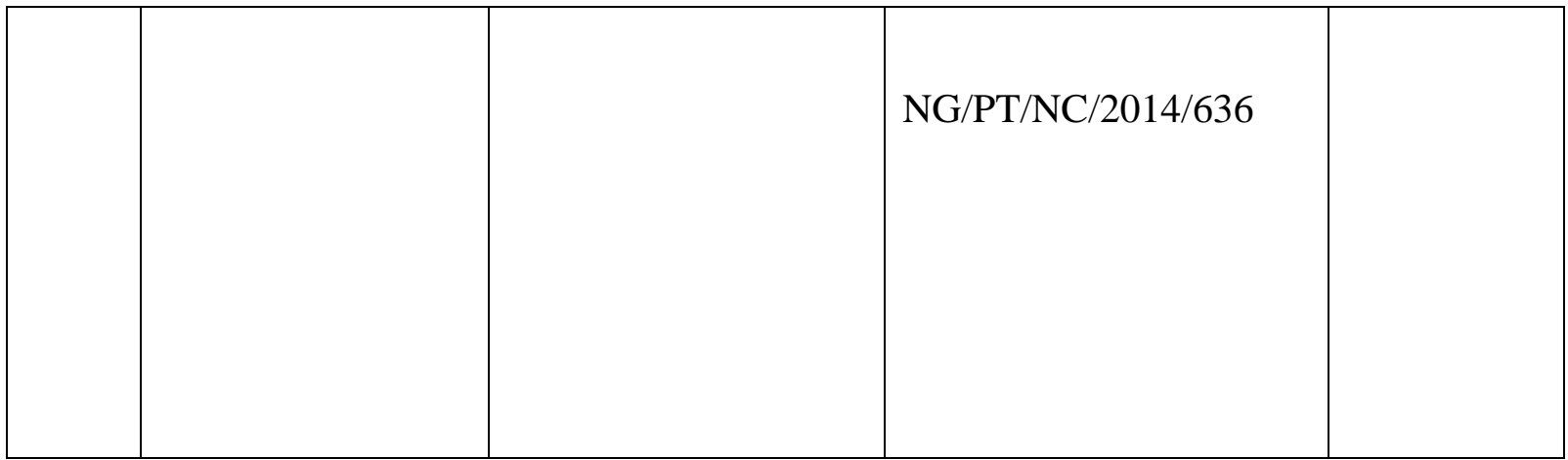

Through the Grant researches, the Fund have registered three intellectual properties and patents from an initial conceptual design that started in 2007. The Grant's concept development and award lasted for three years before actual commencement of research activities. Table 2 represents selected research grants funded between 2012 - 2020, some of which have high potential for intellectual property rights and patents. The economic benefits of the funded researches to the industry and the society are key performance indicators for the annual evaluation of the programme. In the contest of satisfactory programme administration, it is evidenced that the research grant programmes have successfully addressed identified problems of the industry and meet the expectation of the PTDF over the period. There are high levels manpower development inherent in the research programme that have earned industry recognitions when it is benchmarked with the level of acceptance of the research products for the overall meets of its purposes.

The structure of the programme requires that competent team-lead (Lead Researcher) from recognized institutions or research centers with requisite capacity to conduct research, drive the research process for the Fund. Experienced supervisory team of subject matter experts are assigned the responsibilities of independent assessment and evaluation of the research progress of the Lead Researchers. In table 3, selected themes and sub-themes of the research grant competition programme is highlighted. These themes are developed for the industry based on the need assessment from the study report within five years. The skills gap audit of the industry serves as an enabler for the identification of the specific needs of the industry and thus, form the grounds for the development of research themes and sub-themes for the advancement of research in solving such problems.

Every research cycle has different research themes and sub-themes developed for effective grant competition among shortlisted applicants based on defined criteria for selection of qualified proposals, (Neeka, 2019). Essentially, proposals submission constitutes the second stage the research processes after an acceptable concept note. However, there could be a straight proposal evaluation process without the intermediary of a concept note or expression of interest. 
Table 2: Selected funded Grant Researches (2012 - 2020).

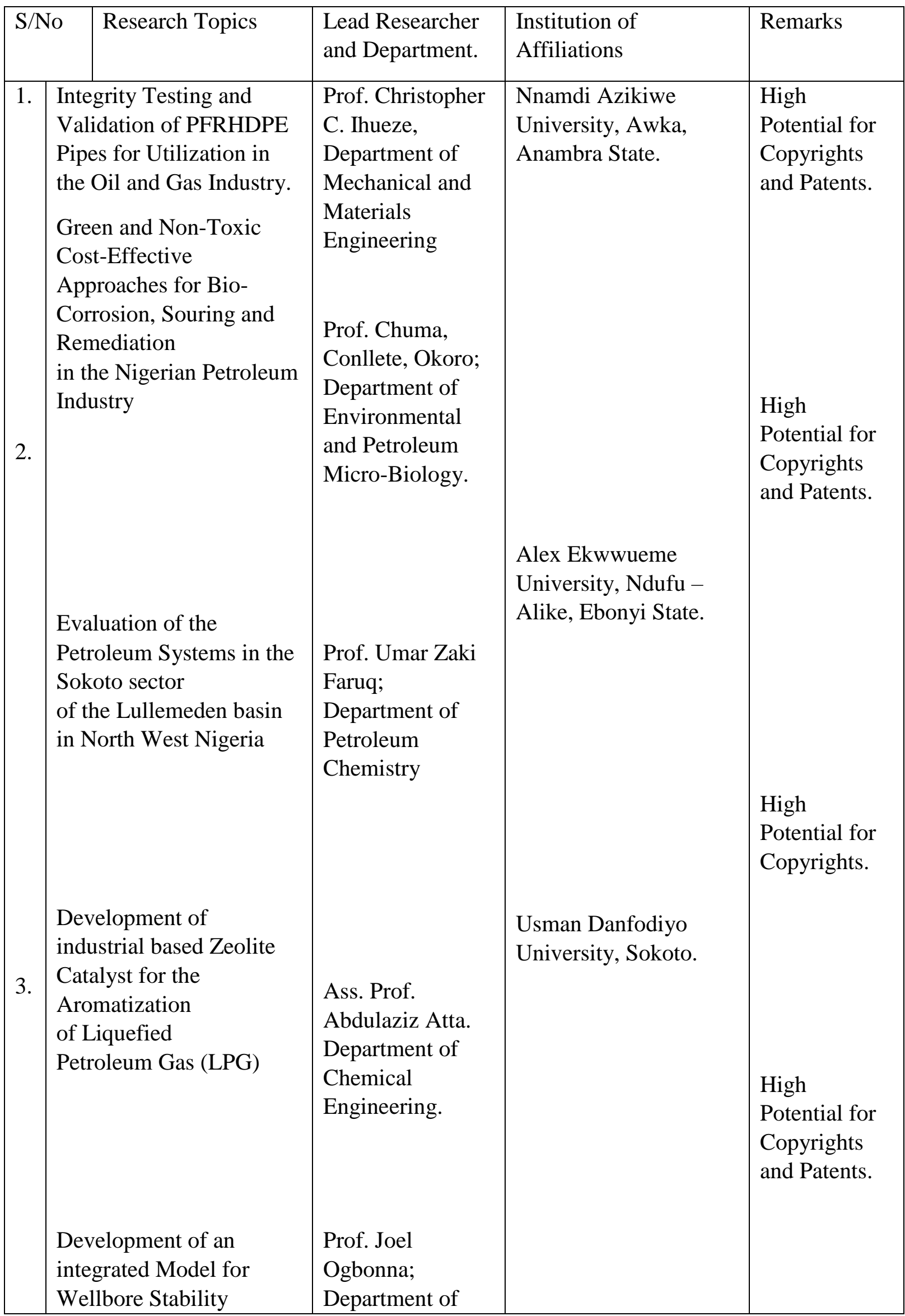




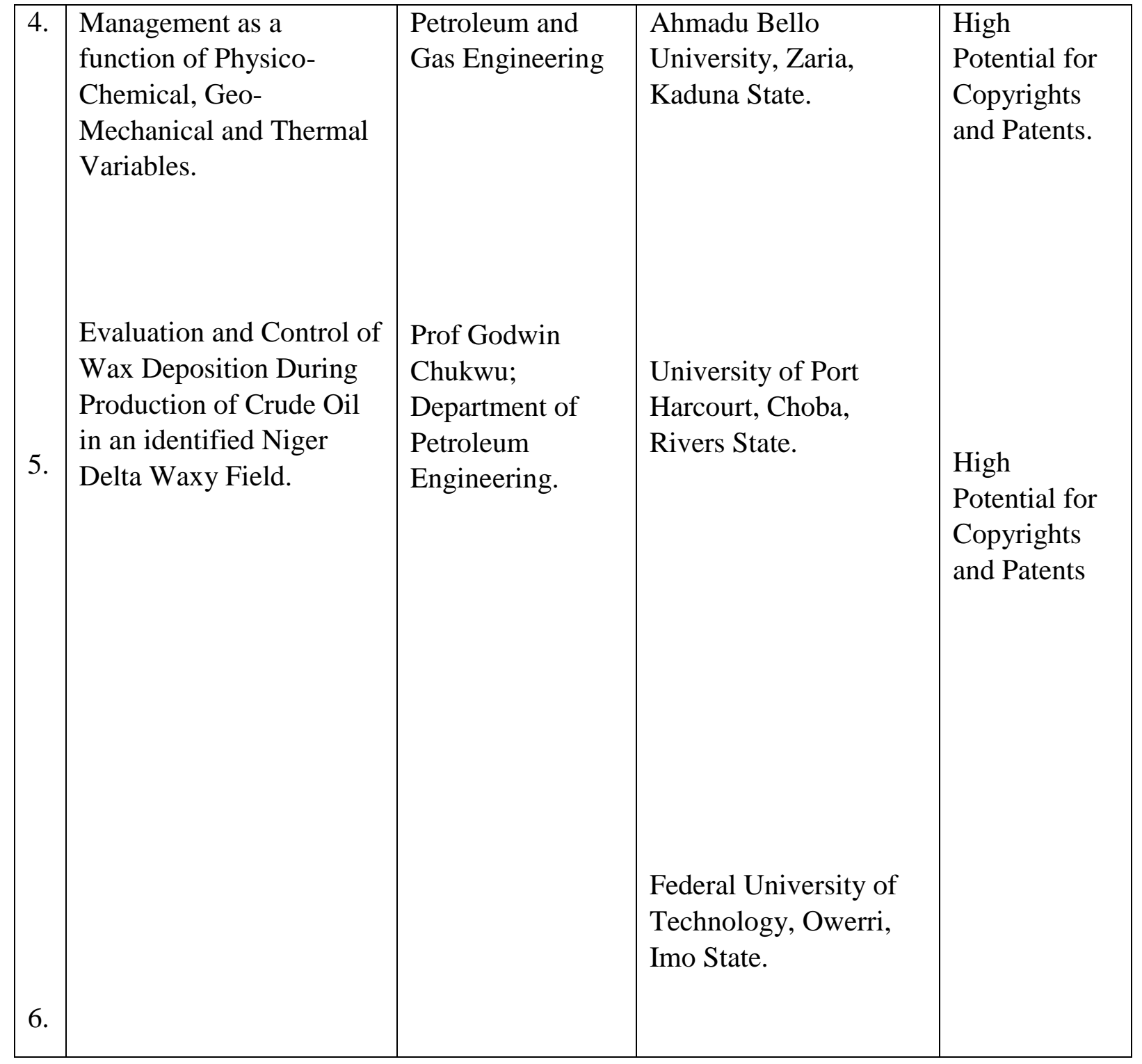

Similarly, Table 3 covers research demands in the upstream, mid and downstream operations of the industry. For example, the upstream focus hinged on the geology of the Nigerian inland and offshore basins in the Niger-Delta, Anambra, Chad and Dahomey, etc. Hydrocarbon prospecting from source rocks, geo-chemical analysis and geo-mechanics are studied with deep intent to increase the hydrocarbon prospectivity of the country. The Mid and Downstream covers hydrocarbon production and refining processes. Asset management strategies and manufacturing of oil and gas materials have been identified as major challenges to the optimization operations of the oil industry. More areas of research opportunities are being developed for the expansion of the frontiers in the downstream research corridors. It is also believed that areas of fiscal and legal frameworks shall be explore soon to strengthen research in policy development and administration for the country, as part of the technology and innovation mandate implementation strategy of the Fund. Table 4 represents the current eight professorial chairs in selected Federal Universities in the country. The Fund's endowment programme began in 2002 and has gain tremendous traction with evident based results, proffering solutions to industry problems, building capacity of Nigerians and leading teaching and learning programmes in the Departments of the endowment. In recent times, training and publications have been emphasized with the intent to grow new breeds of professionals in the area of endowment for seamless succession plan for the university. 
Copyrights and Patents from the various research works have been obtained and documented for global recognition. The process is on-going, and the strategies are also been modified in the interest of all stakeholders. While endowment research combines both teaching and learning with industry research, there are tendencies that bench-scale studies suitable for student's project work are intertwined with expected industry standards. Such sequence helps in the development of technology along the research value-chain (Kelvin, 2014).

Table 3: Concise Grant Research themes and Sub-themes (2008 - 2016).

\begin{tabular}{|c|c|c|}
\hline $\mathbf{S N}$ & THEMES & SUB-THEMES \\
\hline 1 & $\begin{array}{l}\text { Petroleum Prospecting and } \\
\text { Exploration }\end{array}$ & $\begin{array}{l}\text { - Reserves Potential of Inland sedimentary } \\
\text { Basins } \\
\text { - Shale Resource Systems/Plays of Nigeria }\end{array}$ \\
\hline 2 & $\begin{array}{lll}\text { Petroleum } & \text { Production } & \text { and } \\
\text { Exploration } & & \end{array}$ & $\begin{array}{l}\text { - Advanced Smart Well Technology and co- } \\
\text { mingle Production } \\
\text { - Development of oil fields chemicals from } \\
\text { local raw materials } \\
\text { - Design of mechatronics in offshore } \\
\text { systems. } \\
\text { - Corrosion prevention, control and } \\
\text { monitoring } \\
\text { - Gas development and commercialization } \\
\text { - Flow assurance strategies (wax, hydrates, } \\
\text { asphaltenes) }\end{array}$ \\
\hline 3 & $\begin{array}{lll}\text { Petroleum } & \text { Refining } & \text { and } \\
\text { Petrochemicals } & & \end{array}$ & $\begin{array}{l}\text { - Development of construction materials and } \\
\text { catalysts in alkylation process. } \\
\text { - Corrosion in condensate systems. }\end{array}$ \\
\hline 4 & $\begin{array}{l}\text { Renewable and unconventional } \\
\text { energy resources }\end{array}$ & $\begin{array}{l}\text { - Technological development of biofuels } \\
\text { from non-food feedstock. } \\
\text { - Assessment, development and deployment } \\
\text { strategies for pilot renewable energy } \\
\text { systems. }\end{array}$ \\
\hline 5 & $\begin{array}{l}\text { Petroleum Exploration and } \\
\text { Prospecting of Inland Basins, } \\
\text { Onshore/Shallow Offshore, } \\
\text { Deepwater Niger Delta }\end{array}$ & $\begin{array}{l}\text { - Reserves Potential of Inland Sedimentary } \\
\text { Basins } \\
\text { - Shale Hydrocarbon Reserves } \\
\text { Systems/plays of Nigeria } \\
\text { - } \text { Basin Evolution and Basin Modeling } \\
\text { - HP/HT Challenges in Niger Delta }\end{array}$ \\
\hline
\end{tabular}




\begin{tabular}{|c|c|c|}
\hline 6 & $\begin{array}{l}\text { Petroleum Production and } \\
\text { Exploitation }\end{array}$ & $\begin{array}{l}\text { - Advanced smart well Technology and co } \\
\text { - } \text { - Desingled Production of Mechatronics in Offshore } \\
\text { System } \\
\text { - Flow Assurance } \\
\text { - Gas Exploration and Exploitation }\end{array}$ \\
\hline 7 & $\begin{array}{l}\text { Renewable Energy and } \\
\text { Unconventional Resources }\end{array}$ & $\begin{array}{l}\text { - Geothermal Energy Resources } \\
\text { - Production of Photo - Voltaic cells from } \\
\text { local materials }\end{array}$ \\
\hline 8 & $\begin{array}{l}\text { Environmental Management and } \\
\text { Protection }\end{array}$ & - Novel Technique for Remediation \\
\hline
\end{tabular}

Table 4: Professorial Endowment Chairs in Eight Federal Universities in Nigeria. (2017 -2020)

\begin{tabular}{|c|c|c|c|c|}
\hline S/No & Research Type & Research area & Chair Professor & University \\
\hline 1. & $\begin{array}{l}\text { Endowment } \\
\text { Research in } \\
\text { Petroleum } \\
\text { Engineering. } \\
\end{array}$ & $\begin{array}{l}\text { Flow Assurance } \\
\text { Studies of the } \\
\text { Offshore Niger Delta, } \\
\text { Advanced } \\
\text { Thermodynamic } \\
\text { Equilibrium Models } \\
\text { in Flow Assurance } \\
\text { studies, Reservoir } \\
\text { Fluid } \\
\text { Characterization } \\
\text { from Niger Delta } \\
\text { Field. }\end{array}$ & Prof Sunday Isehunwa & $\begin{array}{l}\text { University } \\
\text { of Ibadan, } \\
\text { Department } \\
\text { of } \\
\text { Petroleum } \\
\text { Engineering. }\end{array}$ \\
\hline & $\begin{array}{l}\text { Endowment } \\
\text { Research in Gas } \\
\text { Engineering }\end{array}$ & $\begin{array}{l}\text { Quantification, } \\
\text { Characterization, } \\
\text { Storage and } \\
\text { Utilization of Natural } \\
\text { Gas for Domestic and } \\
\text { Industrial use. }\end{array}$ & & \\
\hline 2. & & & Prof. Dulu Appah. & $\begin{array}{l}\text { University } \\
\text { of Port } \\
\text { Harcourt, } \\
\text { Department }\end{array}$ \\
\hline
\end{tabular}




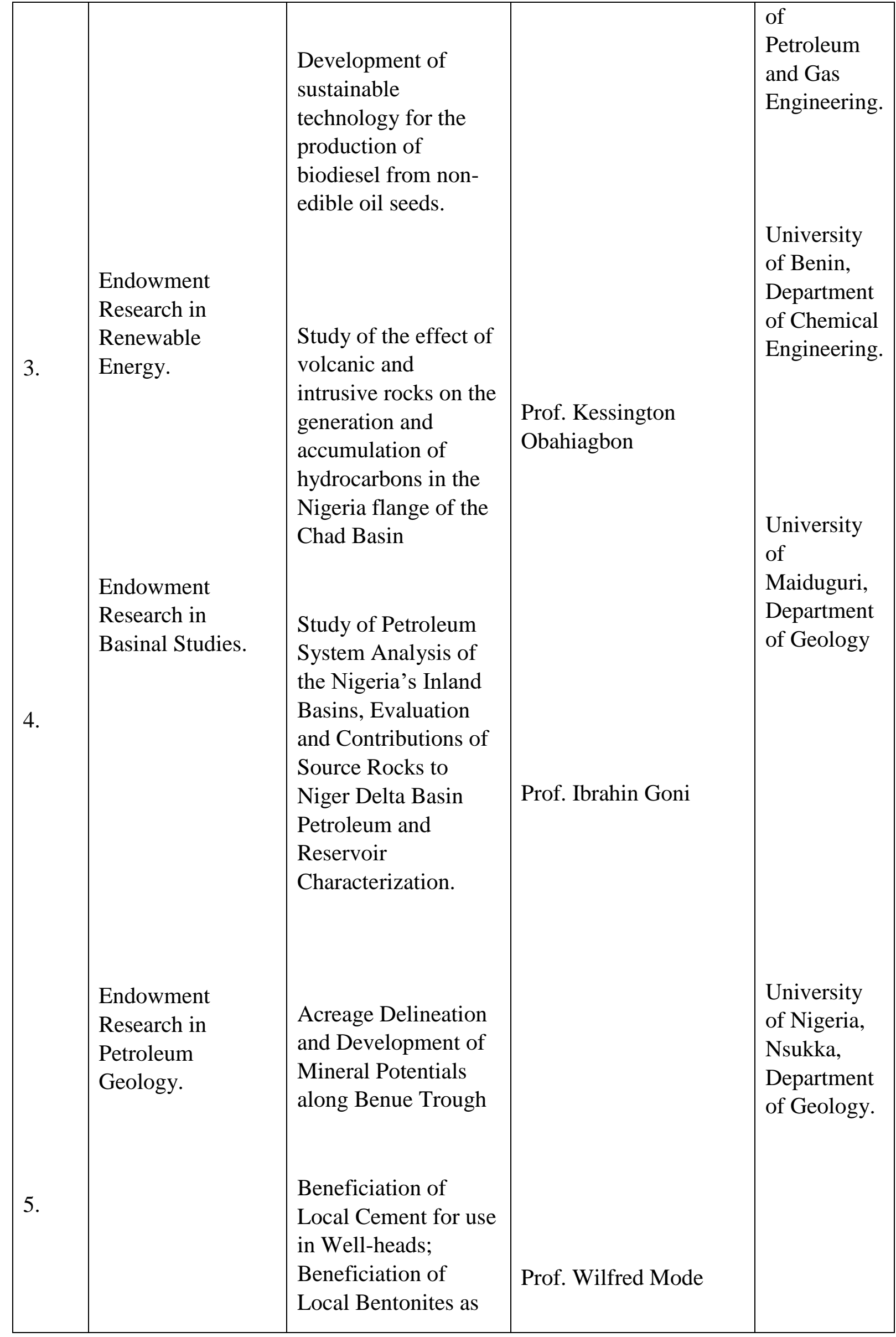




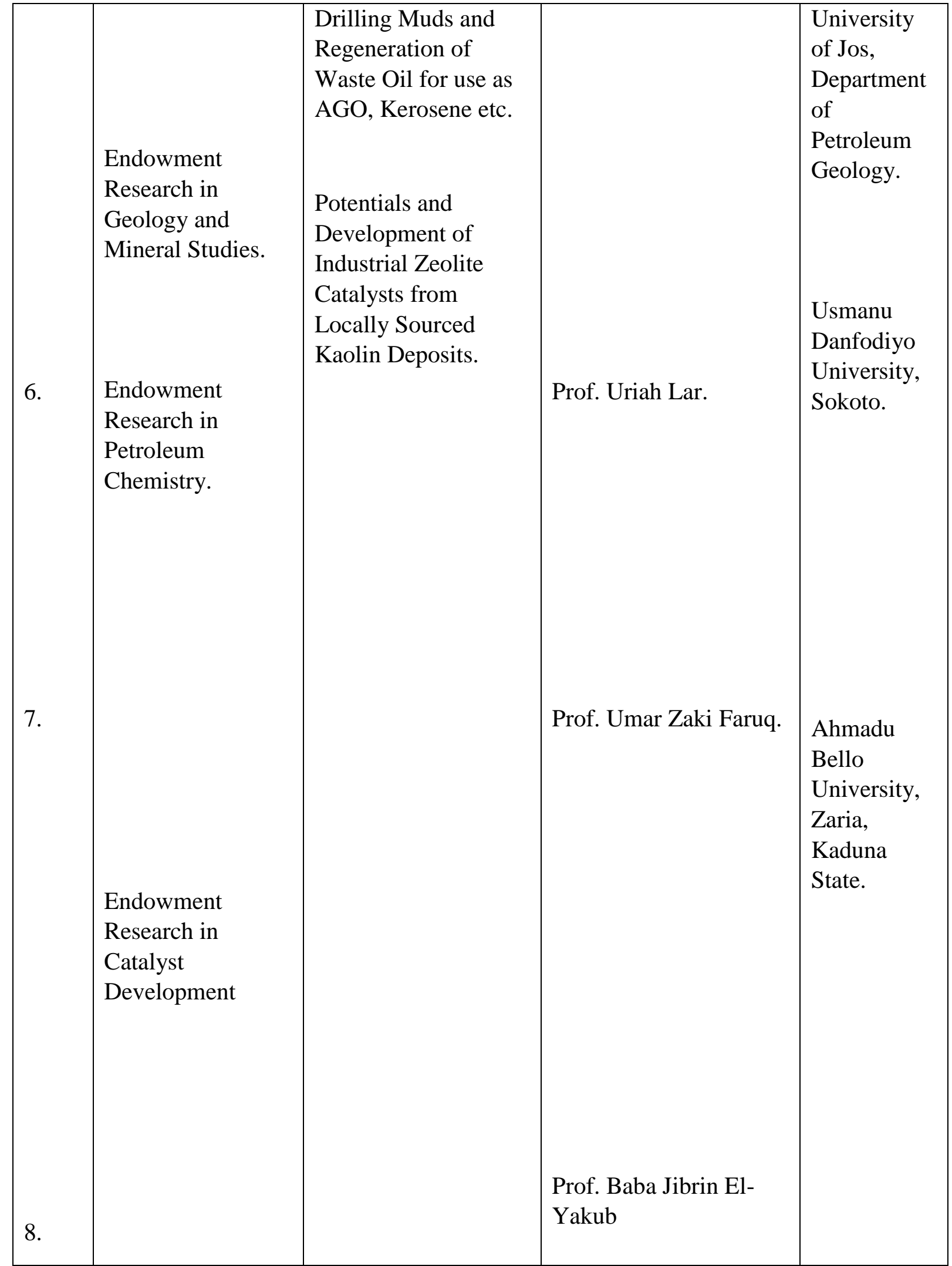




\section{0: CONCLUSION AND RECOMMENDATION.}

The strategic direction of the PTDF should be directed at effective and efficient sustainable funding of local researches for global applications in the petroleum and related industries. This is because the future of national development is for those who can think of tomorrow and any organization or company known for research development and innovation will stand out among comity of organizations globally. More researches should be developed to expand the frontiers of the Fund's mandate and explore ways of generation additional income through the window of commercialization of research products. More research centers should be opened for the purposes of increasing sources of cutting-edge solutions to the industry. The urgent need to establish standard research laboratories for the analysis and effective monitoring of samples for the researchers is expedient. Synergy and strategy based on well-articulated plan of work and, the engagement of local expertise with proven records of achievement both locally and internationally, stand out as the best approach for the success and impactful breakthroughs for the Fund. It is expedient that researchers and research management should embrace the new normal from Covid-19 and leverage on the use of technology in monitoring end evaluation, seminars and workshops where applicable to cut down the cost of research. This is the way to grow the economy and develop the petroleum industry for wealth creation using research development and innovation.

\section{0: REFERENCES}

Olayinka Agboola (2018): Unpublished R\&D presentation on the management and implementation of the PTDF funded endowment programme (2002-2018); National Board of Trustee Meeting, Executive Secretary's Conference Room, PTDF Main Building Abuja.

Bamiro, O.A (2019): Structuring and Stimulating Tertiary Education Institutes (TEIs) for Optimal R\&D Productivity. TetFund workshop for University Research Administrators, United Arab Emirate (DUBAI), December 2019.

Neeka Jacob (2020): R\&D in the Petroleum Industry; from Wellbore to Environmental Safety for Sustainable Development. A paper presented at the TetFund Capacity Building Workshops for Nigerian University Research Administrators. United Arab Emirate (DUBAI), January 2020.

Kelvin, D.H Bob-Manuel (2014): Technical Report Writing and Presentation for Students, Engineers and Scientists. Springfield Publishers Ltd, New Owerri Imo State, Pp.48.

Haruna Mohammed, (2018): Innovative Strategies in Programme Implementation in the Oil and Gas Industry: The PTDF Research Experience, in Technology Knowledge Sharing Programme. PTDF Digest, Pp.52 -53.

Unpublished report of the Committee on the Potential Impact of COVID-19 on PTDF Operations: A dynamic response plan to ensure the continuity of PTDF operations submitted to the Executive Secretary, PTDF Main Building, Abuja Nigeria, April 2020.

Darma, M.R and Jacob N.B (2013): Critical Review of enablers and inhibitors of knowledge creation and sharing in the oil and gas industry in Nigeria. Proceedings of the $1^{\text {st }}$ International Conference and Technical Exhibition on Petroleum, Refining and Petrochemicals, Port Harcourt, Pp 133 -140.

Neeka Jacob, Agboola Olayinka and Jide Adebulehin (2018): Recession to Recovery: Essentials of Education and the Role of PTDF in the Development of the Petroleum Industry in Nigeria. Petroleum Technology Development Journal, Pp. 118 - 125.

Neeka Jacob (2019): Unpublished presentation at the TertFund workshop for University Research Administrators, Batch A. United Arab Emirate (DUBAI), December 2019.

Neeka Jacob (2020): Research Proposal Writing and Funding Opportunities: Best Practices and Challenges. Technical Paper presented at the Monthly Seminar of the Nigerian Society of Chemical Engineers, September 2020.Available online@www.NSChE.org. 